\title{
Variability of agronomic characters related to resistance to stem canker (Phytophthora palmivora) on duku (Lansium domesticum) along Batanghari River, Sumatra, Indonesia
}

\author{
ISLAH HAYATI ${ }^{1,2, \varphi}$, SURYO WIYONO ${ }^{1, v v}$, WIDODO ${ }^{1}$, SOBIR $^{3, v w v}$ \\ ${ }^{1}$ Department of Plant Protection, Faculty of Agriculture, Institut Pertanian Bogor. Jl. Raya Dramaga, Kampus IPB Darmaga, Bogor 16680, West Java, \\ Indonesia. Tel.: +62-251-8622642, ^^email: swiyono2@yahoo.com , and taniutun@ gmail.com \\ ${ }^{2}$ Faculty of Agriculture, Universitas Jambi. Jl. Lintas Jambi-Muara Bulian Km. 15, Mendalo Darat, Muaro Jambi 36657, Jambi, Indonesia. \\ Tel.: +62-741-583377, `email: islahsaja@gmail.com \\ ${ }^{3}$ Department of Agronomy and Horticulture, Faculty of Agriculture, Institut Pertanian Bogor. Jl. Raya Dramaga, Kampus IPB Darmaga, Bogor 16680,

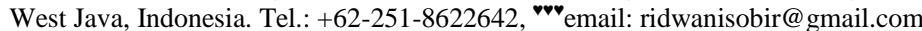

Manuscript received: 11 February 2019. Revision accepted: 25 March 2019.

\begin{abstract}
Hayati I, Wiyono S, Widodo, Sobir. 2019. Variability of agronomic characters related to resistance to stem canker (Phytophthora palmivora) on duku (Lansium domesticum) along Batanghari River, Sumatra, Indonesia. Biodiversitas 20: 1127-1132. Duku (Lansium domesticum Correa) is a tropical favorite fruit in South East Asia, including Indonesia. However, currently stem canker disease caused by Phytophthora palmivora Butler (Butler) has been a serious problem on duku plant in Indonesia, especially in Jambi Province. Since duku is vegetatively propagated, selecting resistant mother trees is an effective approach to overcome the disease. This research was aimed to identify mother trees and their progenies that resistant to stem canker pathogen. The research was conducted in two stages. The first one was morphological identification of healthy-looked mother trees grown at four locations: three in Batanghari and one in Muaro Jambi District. The second stage was analyzing resistant seedling progeny of mother trees identified at the first stage. At the second stage, 3 month old seedlings were inoculated with $P$. palmivora, isolated from rhizosphere of trees grown at the researchs location using Completely Randomized Design. The research found 19 healthy mother trees, and showed similarity index of 0.40 based on eleven identified agronomic characters of mother trees. Cluster analysis revealed 2 identified clusters of mother trees with the identified clusters were independent of plant growth locations. Seedling resistant analysis showed that there were only 5 seedlings expressing resistant traits. Correlation analysis showed that the resistant seedlings were originated from mother trees which tend to have longer leaves, more fruits per branch, more yields, and bigger canopies. This information of the characters can possibly become future reference to choose resistant plant as sources of mother trees to develop and maintain duku populations along the Batanghari River.
\end{abstract}

Keywords: Cluster analysis, correlation, similarity index

\section{INTRODUCTION}

Duku (Lansium domesticum Corr.) is a tropical horticulture crop belonging to the family Meliaceae. There are two distinct botanical varieties of $L$. domesticum, i.e. pubescens and domesticum. Duku is categorized as var. domesticum, which is unlike pubescens, it has a more robust tree, broad-topped and densely foliaged with conspicuously-veined leaflet. The fruits born a cluster with oblong-ovoid or ellipsoid in shape. Fruit skin is thin with pale-brownish color. The fruit is also faintly aromatic and contains little or no milky latex. Duku fruits grown along Batanghari River alluvial are fairly sweet and some are seedless (Techavuthiporn 2018; Hanum 2012).

Duku is originated from Indonesia and widely grown in South East Asia. It is recognized for table fresh fruit and has pharmacological and cosmetic functions. Besides being freshly eaten, the fruits are also used as culinary cooking dish (Te Chato et al. 2005). The seed of the fruit is found to be toxic to malaria parasite through activity of active ingredient tetranortriterpenoids (Saewan et al. 2006). Leaves of duku have chemical ingredient functioned to inhibit human skin tumor formation (Nishizawa et al.
1989). Nishizawa et al. (2010) have developed chemical component extracted in large quantities by a simple procedure namely lansic acid which is potential for hair restoration. Several years later a hair restoration agent, containing lansic acid as the active ingredient, appeared in the market.

Batanghari River alluvial in Jambi Province is the main production area of duku which is mostly grown on the areas with altitude up to $600 \mathrm{~m}$ above sea level (BPTP 2009). In recent years, the overflowing of the Batanghari River has caused recurrent flooding in many areas. The frequency of flooding increases along with an increase in area of flood inundation in Batanghari and Muaro Jambi District. Floods occurring at the end of year 2002 until the beginning of 2003 have caused damage to 2.410 ha agricultural areas and residential areas of 5.504 ha including around 222 villages with 29.502 families. Changing in land cover due to land conversion was assumed as the cause of the flood (Dinas PUPR Provinsi Jambi 2012).

Since 2007, there have been outbreaks of stem canker, causing a decline in fruit production. The disease has resulted in the extinction of duku population in some of the 
main production areas such as Malapari and Terusan village in 2012. The infected fields were recorded of 23.5 $\%$ in Malapari and $44.8 \%$ in Terusan village in 2005 (Handoko 2014). The epidemic has been occurring in Jambi Province. Since 2005, the disease has caused huge number of sudden death of $d u k u$ (BPTP 2009). The disease was identified to be caused by Phytophthora palmivora Butler (Butler) (Handoko 2014), which is soil borne and could be spread by water flow. The recurrent flooding was assumed to be predisposing factor causing the epidemic.

The occurrence of a disease epidemic is inseparable from the presence of inoculum in a region, as well as factors affecting the spread of the inoculum source. Potential inoculum sources include movement of infested soil through equipment between fields, movement of propagules in runoff water from adjacent fields or from infected host in nearby areas, preexisting soil borne inoculum from earlier crops, and tree-to-tree movement once an initial plant is infected (Benson 2006). Ploetz et al. (2007) reviewed that the world's oldest ecosystems are found in the tropics, but it is barely understood. They are so diverse and highly evolved so that diseases that impact crops in these regions can become significant constraints to production, especially when occurring in lowland environments with high rainfall and uniform, warm temperatures. Managing disease in the humid tropics is difficult and it becomes complicated when the affected crops are perennial. The presence of susceptible host tissue over long periods under favorable conditions for disease development makes the diseases of tropical perennial crops pose serious management challenge to eradicate.

Using resistant mother trees is considered among the best option for controlling disease and reducing epidemic problem. For examples, selection and breeding for resistance to Phytophthora have provided an effective means of controlling some Phytophthora diseases of economic importance crops in Indonesia, such as tobacco. Additionally, there were sources of resistance in black pepper against $P$. capsici although they were limited in types. Moreover, late blight of potato and black shank of tobacco have been sufficiently controlled by moderately resistant cultivars. However, so far there is no information available regarding mother trees genotype resistant against $P$. palmivora in duku plants, including stem canker disease (Purwantara et al. 2004). Therefore, in order to expand duku cultivation or substitute the dead plants, mother trees that are resistant to $P$. palmivora are very important to obtain.

Despite the fact of vast number of declining duku population, there are still some healthy trees growing adjacent to infested plants on the field. The healthy trees are assumed to have either resistant ability or just escaped from the disease. It is believed that the first assumption could become a potential source of resistant material for Phytophthora stem canker. To prove that, since disease assay is impossible to apply directly in the field, we generated an experiment of resistance toward stem canker on duku seedlings derived from healthy mother trees. Duku is apomictic plant (Asker and Jerling 1992), meaning that when it is vegetatively propagated plant, it should generate progeny in the same nature as the mothers, including disease-resistant trait. The purpose of this study is to evaluate resistance capability of duku toward stem canker disease in relation to variability of agronomic characters of its mother trees inhabiting along Batanghari River Jambi.

\section{MATERIALS AND METHODS}

\section{Sampling site}

Mother trees (MT) samples were selected in duku main field located at four locations in which three in Batanghari District, Jambi Province, Indonesia, i.e., Teluk, Kampung Baru, and Ture villages, and one in Muaro Jambi District, Jambi Province, Indonesia, i.e., Kota Karang Village (Figure 1). Occurrence of the disease incidence of mother trees is about $70 \%$ in Batanghari District and 30\% in Muaro Jambi District

\section{Agronomic characters observation}

In order to observe agronomic characters of duku, we search for intact mother trees in the field. The selected mother trees were healthy-looked ones and showed no symptoms of canker (Figure 2).

Nineteen intact healthy trees were chosen as samples and observed for their agronomic characters. The characters of the mother trees observed were as follows: leaf length, leaf width, stem circumference, upper leaf, and lower leaves colors, number of branches, canopy size, number of fruits per stalk, bark skin color, and bark texture. To obtain data for leaf characters, 10 stalks of leaves from lower branch were picked. Upper leaf color scoring; 1=light, 2=middle, 3=dark, 4=very dark. Lower leaf scoring; $3=$ light green, $2=$ pale green, $1=$ silvery green. Skin color stem scoring; 7=dark, 6=dark brown, 5=whitish brown, 4=yellowish brown, 3=yellowish green, 2=brownish white, 1=yellowish white. Bark texture scoring; $1=$ mild, $2=$ rough

At the sampling areas, there were also about $30-75 \%$ of diseased trees. The sampling locations were $10 \mathrm{~m}-2 \mathrm{~km}$ distance from the riverbank.

The second stage of this study was to analyze resistance of healthy-looked mother trees. Seeds from 100 fruits of each mother plant were sown to obtain seedlings to be inoculated with pathogen.

\section{Inoculum source}

Pathogen inoculum was obtained from soil of rhizosphere at duku main field as mentioned above. Isolation of the fungi was conducted following protocol of Aryantha et al (2015). First, the soil sample was mixed with sterile water, then the sample was put into green sour apples. The inoculated apple was incubated for several days at room temperature until brown-mold occurred surrounding the inoculation spot. Then pieces of inoculated apple flesh were put onto Potato Agar and Carrot Agar medium. Single culture was obtained by excising a piece of mycelium and culturing on PDA medium. 

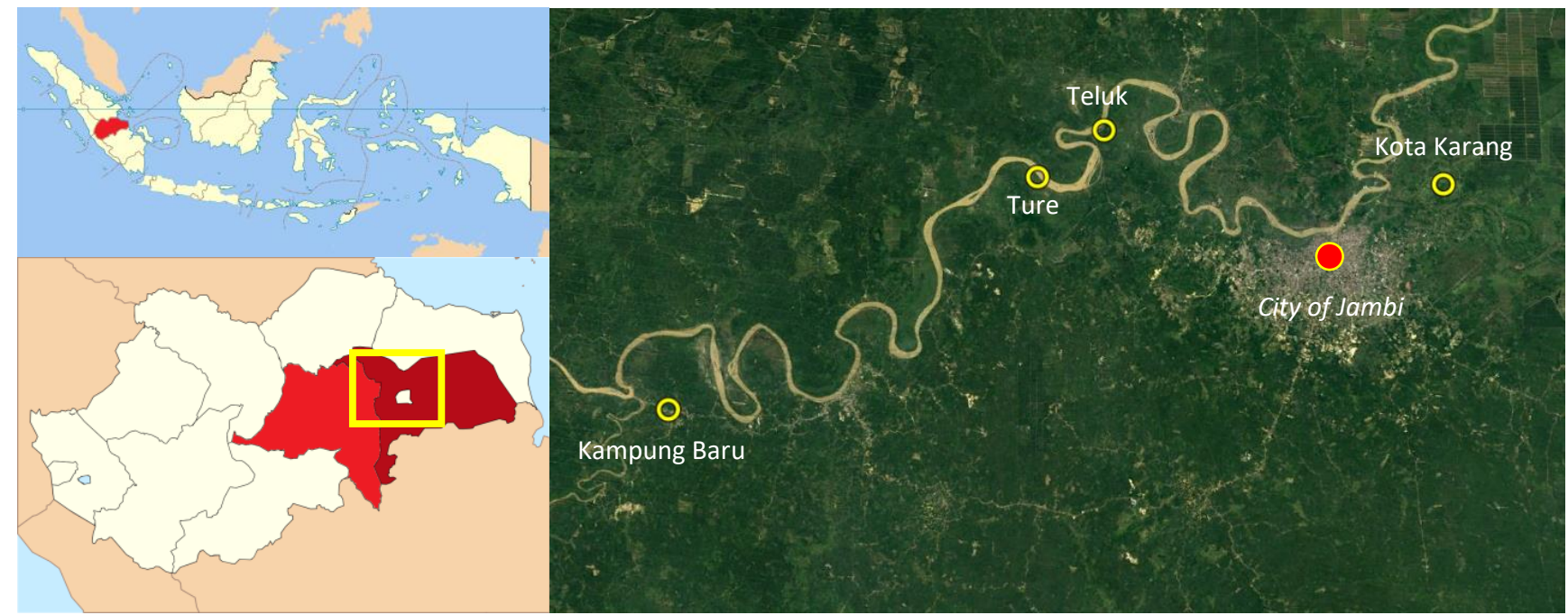

Figure 1. Research locations where duku (Lansium domesticum) mother trees were observed for agronomic characters in Batanghari and Muaro Jambi Districts, Jambi Province, Indonesia

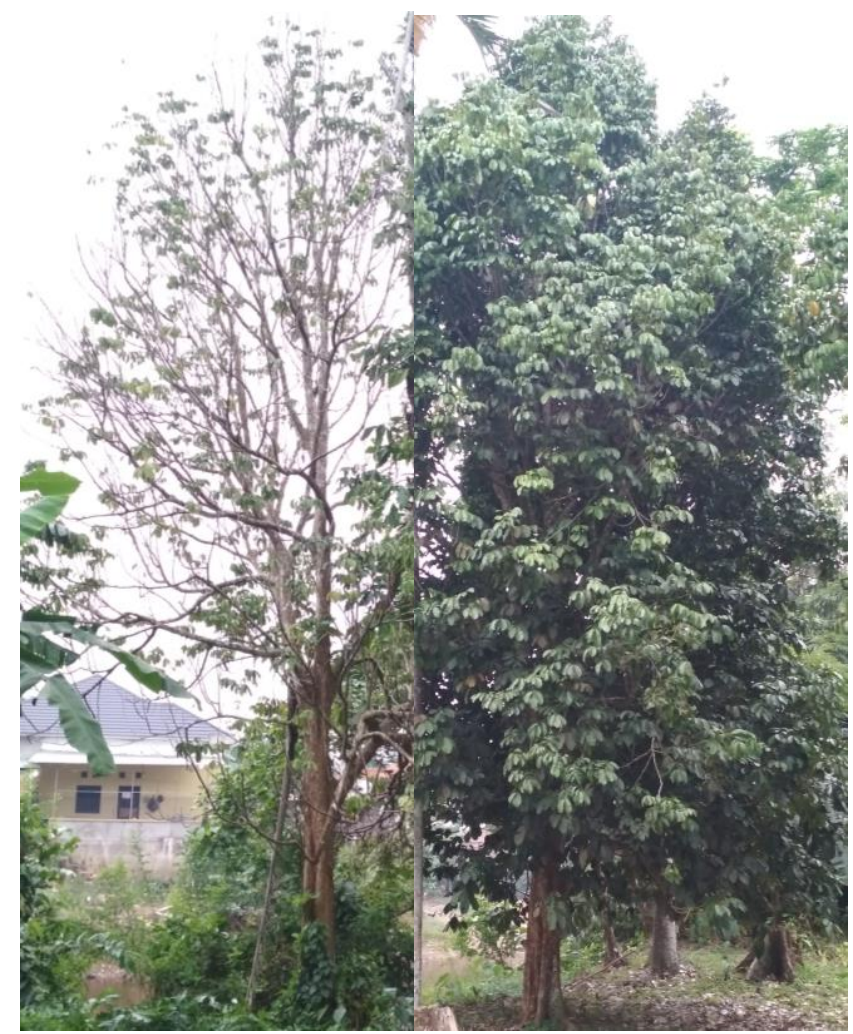

Figure 2. Duku (Lansium domesticum) mother trees showing advance symptoms of canker (left) and healthy-looked one (right).

\section{Seedling resistance analysis}

Resistance analysis toward stem canker pathogen of $P$. palmivora was applied to seedlings derived from nineteen healthy mother trees that have been observed and characterized at the first stage. The seeds were initially germinated on sand media. After reaching a height of approximately $5 \mathrm{~cm}$, the seedlings were transferred to polybags that have been filled with soil media mixed with manure at a proportion of 3: 1. Three-month-old duku seedlings were inoculated with $P$. palmivora through their roots. Culture of pathogen was cut with $5 \mathrm{~mm}$ cork borer and used as an inoculum source. The soil was partly removed and five pieces of inoculum were placed at the root surface and then the soil was returned to its original place (Wu et al. 2016).

\section{Data analysis}

Cluster analysis was conducted and its dendrogram was constructed for studying morphological relationships and grouping them based on quantitative and qualitative agronomic characters. Agronomic characters associated with resistance to pathogens were observed through Spearman correlation. Data analysis were carried using $R$ programming language.

\section{RESULTS AND DISCUSSION}

\section{Agronomic characters}

Table 1 shows the observed quantitative agronomic characters. The longest leaf length was about $28 \mathrm{~cm}$ in the mother tree no. 13, and the shortest was about $15 \mathrm{~cm}$ in the tree no. 4 . The widest leaf was $15 \mathrm{~cm}$ in the tree no. 14 and the shortest was $7 \mathrm{~cm}$ in the mother tree no. 4. The stem circumference ranges from $73 \mathrm{~cm}$ in mother tree no. 4 to $300 \mathrm{~cm}$ on mother tree no. 18. Mother tree no. 9 had the most branches and mother tree no. 1 had the fewest. The highest number of fruit per stalk was 23 on mother tree no. 10 while the lowest was 10 on mother tree no. 7. Mother tree no. 13 had the highest yield, whereas mother tree no. 2 had the lowest. The widest canopy size is possessed by mother tree no. 14

We observed 5 agronomic characters scored qualitatively, namely upper leaf color, lower leaf color, 
bark color, bark texture and canopy size (Table 2). The results showed that all of those characters were polymorphism-having different traits in the same morphological character-bark color being the most one. Mother trees no. 3, 9,13,14,16 had dark green upper leaf and light green lower leaf performance. The remaining trees had very dark upper leaf and pale green lower color.

Cluster analysis was aimed to define the degree of relatedness among observed mother trees. Nineteen duku mother trees genotypes were categorized into 2 clusters with a coefficient of similarity of 0.4 , consisting of 14 populations in group I and 5 populations in group II (Figure 3 ). Dendrogram at a distance of 0.12 formed four mother trees similar in morphology, namely mother trees no. 2 and 5 , mother trees no. 17 and 19. At a distance of 0.17 to 0.19 , there were four populations which had similarities, namely mother trees no. 7 and 12, mother trees no. 10 and 15, mother trees no. 13 and 16. More populations were clustered at a distance of 0.25 to 0.30 , except for mother trees no. 4 and 14. But at a distance of 0.37 there was one population that was not similar namely mother tree no. 3 in group II (Figure 2). The mother trees number 3, 9, 13, 14 and 16 were from Batanghari District, while the others were grown scattered in Batanghari and Muaro Jambi Districts. From these findings, it appeared that the groups were independent of growth locations.

\section{Seedling resistance analysis}

Analysis of resistance to $P$. palmivora on seedlings regarding mother trees of origin, showed that there are five resistant origins with mother trees number 2,3,4,7,12 (Figure 4). Mother tree no. 1 was the only origin fully susceptible to pathogen. There were 5 origins being considered moderately resistant toward the pathogen. Mother trees no. 5,8,10,11,13,14 were included in 50 percent susceptible. We found 3 susceptible origins against stem canker disease.
Agronomic traits related positively to seedling resistance were leaf length and number of fruit per stalk (Table 3). Number of fruit per stalk correlates positively with canopy size. Leaf length correlates significantly with yield. Yield correlates positively with bark texture as well as number of branch. Upper leaf color and lower leaf color correlate negatively with leaf length.

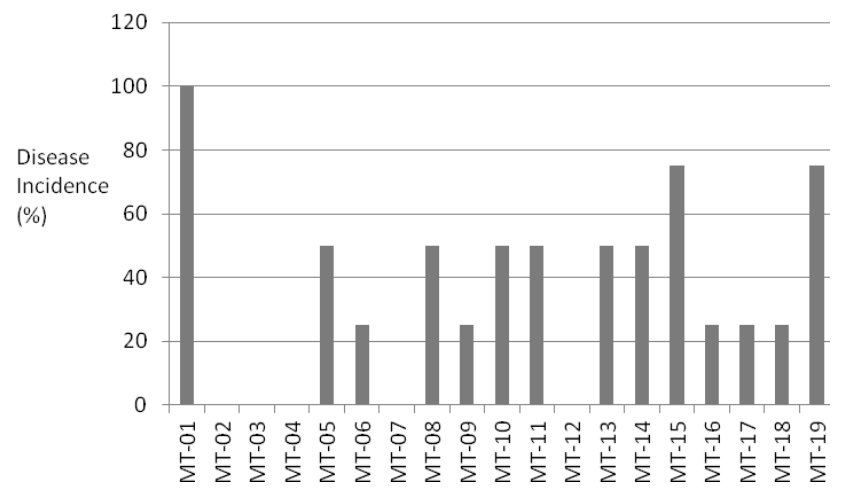

Figure 4. Resistance of mother tree of origin toward stem canker Phytophthora palmivora. MT: mother tree

Table 1. Quantitative agronomic characters and plant identification number of duku (Lansium domesticum) mother trees

\begin{tabular}{lll}
\hline Characters & Minimum & Maximum \\
\hline Leaf length $(\mathrm{cm})$ & $15(\mathrm{MT}-04)$ & $28(\mathrm{MT}-13)$ \\
Leaf width $(\mathrm{cm})$ & $7(\mathrm{MT}-04)$ & $15(\mathrm{MT}-14)$ \\
Stem circumference $(\mathrm{cm})$ & $73(\mathrm{MT}-03)$ & $300(\mathrm{MT}-18)$ \\
Number of branch & $11(\mathrm{MT}-01)$ & $36(\mathrm{MT}-09)$ \\
Number. of fruit per stalk & $10(\mathrm{MT}-07)$ & $23(\mathrm{MT}-10)$ \\
Yield/tree $(\mathrm{kg})$ & $65(\mathrm{MT}-02)$ & $370(\mathrm{MT}-13)$ \\
\hline
\end{tabular}

Table 2. Qualitative agronomic characters variation among duku(Lansium domesticum) mother trees

\begin{tabular}{|c|c|c|c|c|c|c|c|}
\hline $\begin{array}{l}\text { Upper leaf color } \\
\text { No. of tree }\end{array}$ & $\begin{array}{l}\text { Light }=1 \\
0\end{array}$ & $\begin{array}{l}\text { Moderate =2 } \\
\text { 0 }\end{array}$ & $\begin{array}{l}\text { Dark = 3 } \\
5\end{array}$ & $\begin{array}{l}\text { Very dark }=4 \\
14\end{array}$ & & & \\
\hline $\begin{array}{l}\text { Lower leaf color } \\
\text { No. of tree }\end{array}$ & $\begin{array}{l}\text { Silvery green }=1 \\
0\end{array}$ & $\begin{array}{l}\text { Pale green }=2 \\
5\end{array}$ & \multicolumn{4}{|c|}{ Light green $=3$} & \\
\hline $\begin{array}{l}\text { Bark texture } \\
\text { No. of tree }\end{array}$ & $\begin{array}{l}\text { Mild =1 } \\
7\end{array}$ & $\begin{array}{l}\text { Rough }=2 \\
12\end{array}$ & & & & & \\
\hline $\begin{array}{l}\text { Bark color } \\
\text { No. of tree }\end{array}$ & $\begin{array}{l}\text { Yellowish } \\
\text { white }=1 \\
1\end{array}$ & $\begin{array}{l}\text { Brownish } \\
\text { white }=2 \\
2\end{array}$ & $\begin{array}{l}\text { Yellowish } \\
\text { green }=3 \\
2\end{array}$ & $\begin{array}{l}\text { Yellowish } \\
\text { brown }=4 \\
7\end{array}$ & $\begin{array}{l}\text { Whitish } \\
\text { brown }=5 \\
5\end{array}$ & $\begin{array}{l}\text { Yellowish } \\
\text { brown }=6 \\
2\end{array}$ & $\begin{array}{l}\text { Dark }=7 \\
0\end{array}$ \\
\hline $\begin{array}{l}\text { Canopy } \\
\text { No. of tree }\end{array}$ & $\begin{array}{l}\text { Narrow }=1 \\
6\end{array}$ & $\begin{array}{l}\text { Medium }=2 \\
7\end{array}$ & $\begin{array}{l}\text { Wide }=3 \\
5\end{array}$ & $\begin{array}{l}\text { Very } \text { wide }=4 \\
1\end{array}$ & & & \\
\hline
\end{tabular}


Table 3. Correlation among agronomic characters and seedling resistance of duku (Lansium domesticum) mother plants

\begin{tabular}{|c|c|c|c|c|c|c|c|c|c|c|c|}
\hline & $\mathbf{L L}$ & $\mathbf{L W}$ & SC & ULC & LLC & NB & FS & $\mathbf{Y}$ & BSC & BT & C \\
\hline LW & $0,1391^{\mathrm{ns}}$ & & & & & & & & & & \\
\hline SC & $-0,0080^{\mathrm{ns}}$ & $0,0289^{\mathrm{ns}}$ & & & & & & & & & \\
\hline ULC & $-0,3605^{*}$ & $-0,4036^{*}$ & $0,362 *$ & & & & & & & & \\
\hline LLC & $-0,3605^{*}$ & $-0,4036^{*}$ & $0,362 *$ & $1 * *$ & & & & & & & \\
\hline NB & $0,1976^{\mathrm{ns}}$ & $-0,2093^{\mathrm{ns}}$ & $0,1103^{\mathrm{ns}}$ & $-0,204^{\mathrm{ns}}$ & $-0,204^{\mathrm{ns}}$ & & & & & & \\
\hline FS & $0,1556^{\mathrm{ns}}$ & $-0,0055^{\mathrm{ns}}$ & $0,094^{\mathrm{ns}}$ & $-0,0953^{\mathrm{ns}}$ & $-0,095^{\mathrm{ns}}$ & $-0,0407^{\mathrm{ns}}$ & & & & & \\
\hline $\mathrm{Y}$ & $0,3257 *$ & $-0,1404^{\mathrm{ns}}$ & $0,0388^{\mathrm{ns}}$ & $-0,2371^{\mathrm{ns}}$ & $-0,237^{\mathrm{ns}}$ & $0,6707 *$ & $0,2491^{\mathrm{ns}}$ & & & & \\
\hline BSC & $0,2020^{\mathrm{ns}}$ & $0,4752 *$ & $-0,2125^{\mathrm{rn}}$ & $-0,1842^{\mathrm{ns}}$ & $-0,184^{\mathrm{ns}}$ & $0,0731^{\mathrm{ns}}$ & $-0,2575^{\mathrm{ns}}$ & $0,1226^{\mathrm{ns}}$ & & & \\
\hline BT & $0,1664^{\mathrm{ns}}$ & $0,2348^{\mathrm{ns}}$ & $0,5106^{*}$ & $-0,2087^{\mathrm{ns}}$ & $-0,209^{\mathrm{ns}}$ & $0,3433^{*}$ & $0,1251^{\mathrm{ns}}$ & $0,3540 *$ & $-0,0841^{\mathrm{ns}}$ & & \\
\hline $\mathrm{C}$ & $0,0436^{\mathrm{ns}}$ & $0,2942^{\mathrm{ns}}$ & $-0,1707^{\mathrm{ns}}$ & $-0,234^{\mathrm{ns}}$ & $-0,234^{\mathrm{ns}}$ & $-0,4405^{*}$ & $0,3628 *$ & $-0,0883^{\mathrm{ns}}$ & $0,0914^{\mathrm{ns}}$ & $0,1683^{\mathrm{ns}}$ & \\
\hline DI & $0,3258 *$ & $0,2720^{\mathrm{ns}}$ & $-0,0129^{\mathrm{ns}}$ & $0,113^{\text {ns }}$ & $0,113^{\mathrm{ns}}$ & $-0,2956^{\mathrm{ns}}$ & $0,3866^{*}$ & $-0,0291^{\mathrm{ns}}$ & $0,0014^{\mathrm{ns}}$ & $0,0923^{\mathrm{ns}}$ & $0,2887^{\mathrm{ns}}$ \\
\hline
\end{tabular}

Note: LL: leaf length, LW: leaf width, SC: stem circumference, ULC: upper leaf color, LLC: lower leaf color, NB: number of branch, FS: number of fruit per stalk, Y: yield, BSC: bark skin color, BT: bark texture, C: canopy, *: significant at $\mathrm{p}<0.05$. ${ }^{\text {ns }}$ : non-significant

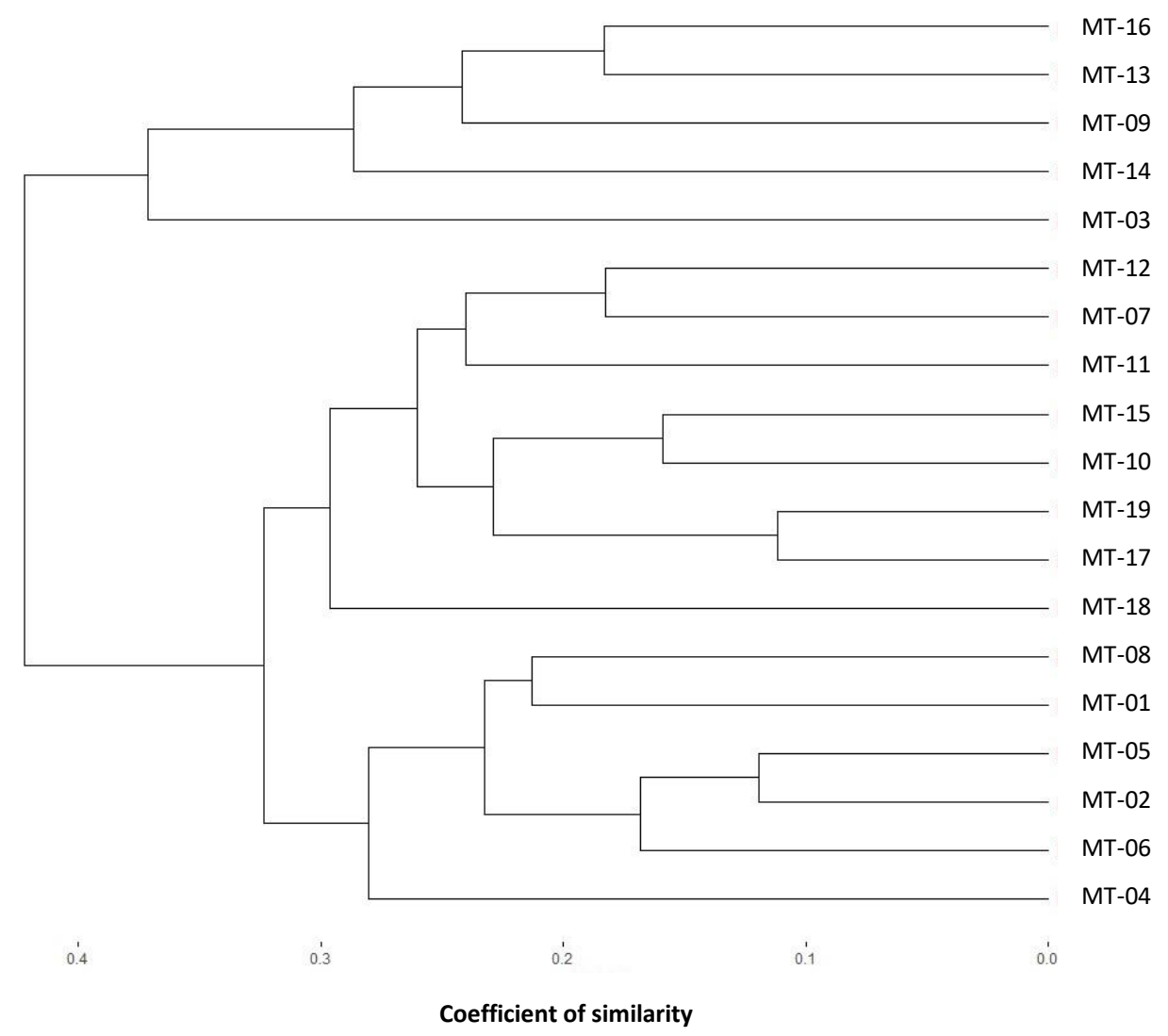

Figure 3. Dendogram of cluster analysis of duku (Lansium domesticum) mother plants classified according to agronomic characters. . MT: mother tree

\section{Discussion}

Duku is a source of income for communities along Batanghari River, Jambi Province, Indonesia. Almost all duku population is not cultivated and grown naturally from their mother trees. Outbreak of stem canker has been deteriorating duku trees and impacting the farmer source of income. The use of resistant trees is a practical method to help reduce the prevalence and spread of this cankercausing pathogen. There have been no studies related to duku plant resistance to diseases, including stem canker.
Our research investigated characters as well as variability of duku that is potentially a source of resistant mother trees. Asker and Jerling (1992) suggested that duku is categorized as apomictic trees. They also mentioned that the character or type of apomixes consists of obligate and facultative apomictic. Obligate apomictic occurs when the offspring is truly uniform and identical to the mother, whereas facultative apomictic is a combination of apomictic and sexual reproduction. Facultative apomictic results in slight variability in the offspring. Apomictic 
seeds have resulted from reproduction process of trees where embryo formation is not preceded by fertilization. Breeding with apomictic seeds produces new trees that have the same properties as the mother. Therefore, resistance study in trees can be generally applied through 2 approaches, mother trees, and their progenies. As such, assaying for disease resistance applied on big tree than on seedling is more complicated if not impossible if and that is the rationale for our second stage experiment.

Cluster analysis has been used in many studies regarding resistance toward pathogen. For examples, Mukherjee et al. (2013) found three clusters of rice genotypes according to their response in respect of the various degree of resistance to rice blast. Afutu (2017) obtained variation in the traits of cowpea that could be used in selecting lines for increasing yields and resistance to the scab disease. He also observed there was a mix of resistant and moderately resistant lines, unique and clearly distinct sub-clustering of lines based on resistance levels.

In this study, we had successfully grown seedlings for resistant screening from 19 mother trees. Five out of 19 mother trees, generated resistant seedlings originating from mother trees number 2, 3, 4,7,12. This study found that mother trees of duku at the field along Batanghari River in Batanghari and Muaro Jambi Districts consisted of 2 groups with $40 \%$ similarity and not related to location where they grow. All morphological indicators of duku mother trees were polymorphism.

Agronomic characterization of mother trees is expected to help identify plant characteristics that are resistant to pathogen attacks (Krisnawati and Adie 2017; Utomo et al. 2005). The agronomic characters that marked the resistance to duku stem canker were longer leaf, more number of fruit per stalks, yields, bigger canopy, as well as more number of branch. All those characters were indicators of older trees and high productivity. Therefore, it is assumed that resistance was partly as a phenomenon of disease escape.

Other additional agronomic characters marked resistance were leaf color and bark texture. Mother trees with lighter leaf color can also be categorized as resistant plants. Rough bark texture may act as means of mechanical barrier toward spore landing and infecting to the stem, since the spore was carried out from soil to stem by running water splashing. Information on agronomic characters of the resistant mother trees has shed light to facing problem of decreasing duku population along Batanghari River. The old trees could be used in selecting mother trees for increasing populations, yields and resistance.

\section{ACKNOWLEDGEMENTS}

Acknowledgment for partly financial support of this work goes to PNBP University of Jambi, Indonesia.

\section{REFERENCES}

Afutu E. 2017. Resistance of cowpea to scab disease and diversity of Sphaceloma sp. occurring in Uganda. [Dissertation]. Makerere University. Kampala, Uganda.

Agrios GN. 2005. Plant Pathology. Elsevier, New York.

Aryantha IP, Santoso PJ, Pancoro A, Suhandono S. 2015. Identification of Phytium and Phytophthora associated with Durian (Durio sp.) in Indonesia: Their molecular and morphological characteristics and distribution. Asian J Plant Pathol 9 (2): 59-71.

Asker SE, Jerling L. 1992. Taxonomic considerations. In: Asker SE, Jerling L (eds). Apomixes in Trees. CRC Press, Boca Raton, FL.

Balai Pengkajian Teknologi Pertanian 2009. Penyakit kanker batang pada tanaman duku. Balai Besar Pengkajian dan Pengembangan Teknologi Pertanian. Badan Penelitian dan Pengembangan Pertanian, Jambi. [Indonesian]

Benson DM, Grand LF, Vernia CS, Gottwald TR. 2006. Temporal and spatial epidemiology of Phytophthotra root rot in Fraser Fir plantations. Plant Dis 90: 1171-1180.

Handoko S. 2014. Kajian Epidemi Penyakit Kanker Batang Duku di Provinsi Jambi. [Dissertation] Gajah Mada University, Yogyakarta. [Indonesian]

Hanum L, Kasiamdari RS, Santosa, Rugayah. 2013. The phylogenetic relationship among varieties of Lansium domesticum Correa based on ITS rDNA sequence. Indonesian J Biotechnol 18 (2): 123-132.

Hung PM, Wattanachai P, Kasem S, Poaim S. 2015. Biological control of Phytophthora palmivora causing root rot of Pomelo using Chaetomium spp. Mycobiology 43: 63-70.

Krisnawati A, Adie M. 2017. Characterization and performance of agronomic characters of soybean genotypes resistant to pod shattering. Biodiversitas 18: 1158-1164.

Dinas PUPR Provinsi Jambi. 2012. Pengelolaan Sumber Daya Air Wilayah Sungai Batanghari. Dinas PUPR Provinsi Jambi, Jambi. [Indonesian]

Mukherjee AK, Mohapatra NK, Nayak P. 2013. Identification of slowblasting rice genotypes through multivariate analysis of components of resistance. J Appl Biol Sci 8: 125-138

Nishizawa M, Emura M, Yamada H, Shiro M, Chairul, Hayashi Y, Tokuda V. 1989. Isolation of a new cycloartanoid triterpene from leaves of Lansium domesticum novel skin-tumor promotion inhibitors. Tetrahedron Lett 30 (41): 5615-5618.

Nishizawa M, Imagawa H, Yamamoto H. 2010. A new catalyst for organic synthesis: mercuric triplate. Org Bomol Chem 8 (3): 511-521

Purwantara A, Manohara D, Warokka J. 2004. Phytophthora diseases in Indonesia. In: Drenth A, Guest D (eds). Diversity and Management of Phytophthora in Southeast Asia. ACIAR Monograph No. 114. ACIAR, Canberra.

Ploetz RC. 2007. Diseases of tropical perennial crop: challenging problems in diverse environments. Plant Dis 61: 644-663.

Saewan N, Sutherland J, Chantrapomma K. 2006. Antimalarial tetranortriterpenoids from the seeds of Lansium domesticum Corr. Phytochemistry 67: 2288-2293.

Te Chato S, Lim M, Mashahiro M. 2005. Comparison of cultivar identification method of longkong, langsat and duku: Lansium spp. Songklanakarin J Sci Technol 27: 465-472.

Techavuthiporn C. 2018. Langsat-Lansium domesticum. Exotic Fruits. DOI: 10.1016/b978-0-12-803138-4.00036-8

Utomo S, Setiowati E, Akin H. 2005. Ketahanan terhadap penyakit bercak daun lambat (Cercosporidium personatum) dan karakter agronomi kacang tanah famili F5 keturunan persilangan kelinci $\mathrm{x}$ southern runner. J HPT Trop 5 (2): 104-112. [Indonesian]

Wu X, Yuan XL, Zhi FF, Xi PG. 2016. First report of root rot of Pogostemon cablin caused by Phytophthora palmivora in China. Plant Dis 100: 1249. 